\title{
Term-Notion Dichotomy in Translation
}

\author{
Tatiana V. Tyurneva and Natalia V. Shchurik* \\ Irkutsk State University \\ 3 Karl Marx Str., Irkutsk, 664003, Russia
}

Received 11.02.2018, received in revised form 13.04.2018, accepted 27.04.2018

\begin{abstract}
The paper deals with philosophical problem of term-notion dichotomy. Linguo-semiotic analysis based on discourse community classification and discursive practices helps to distinguish notions and terms. Pragmatics, text type, genres and discourse community very often make a translator transfer terms into notions during the process of translation. Translation of terms by notions differs from translation of terms by terms, because it needs also interpretation. A translator transfers not only terms and lexical units but discourses.
\end{abstract}

Keywords: notion, term, discourse of consensus, discourse of expert community, sign, interpretation, translation, symmetry, asymmetry.

DOI: $10.17516 / 1997-1370-0275$.

Research area: linguistics.

Nowadays scientific community is disputing mental entities differentiation and their possible correlation with a certain discourse type (Kaplunenko, 2007; Krapivkina, 2016; Tyurneva, 2012). We would focus on the notion and term, which have long been considered mainly in the frame of logic and philosophy.

The purposes of this paper are threefold. The first is to consider the notion and term on the basis of belonging to a certain type of discursive community. The second purpose is to illustrate the vector of mental entities interpretation. And the last purpose is to demonstrate how the termnotion dichotomy is applied in translation.

1. Notions are often defined as one of the main forms of thinking that is why its important role in cognition is emphasized. Transition from a sensual step of cognition to abstract thinking is characterized by moving from perceptions and representations to the reflection of the world in forms of notions, judgments and theories as it is through the notions that thinking acquires the character of the generalized reflection of reality.

In dialectical logic of Hegel the notion is considered as a member of triadic relations genesis - essence - notion, where the last carries the pure sense synonymic to logos. It is a category that embodies the essence of being. Hegel says that interrelation of notions forms a network, the nodes of which are numerous categories. This interweaving of senses was called "conceptual network" (Hegel, 1998). Results summarizing the data of natural being and experience are the essence of notions and they, in turn, record significant characteristics of objective reality phenomena. Notions do not exist in a real world;

(c) Siberian Federal University. All rights reserved

* Corresponding author E-mail address: amistad@yandex.ru 
they arise in our consciousness and replace objects, phenomena, processes, emotions, etc. by certain images making the natural language of communication more succinct. Thinking becomes knowledge and knowledge is expressed through notions.

Arguing about notion and its content, it is necessary to emphasize that the mental entity possesses certain characteristic features that help to distinguish notions from concepts or terms. Since the notion is a general understanding of something, its characteristics contribute to the delineation of any phenomena, providing an opportunity to define the object of the study and distinguish it from a number of similar ones. Let us say that "snow" or "blood" are naturalscientific notions, the distinctive features of which are evident to any society member. In order to ascertain whether all the characteristics of the notion correspond to the object, we will not judge it at first sight. On the contrary, the object is researched on the part of its various properties. Once this is done "the object 1 is finally coming under the notion 1 , which means it is attributed to the whole number of characteristic features" (Sigwart, 2008: 50).

Let's take a closer look at a number of examples.

So the traditional liberal position in support of giving wide scope to freedom of speech, even for extremists, is losing ground everywhere. (1)

He thought of nothing and was incapable of thinking; but he felt suddenly in his whole being that he had no more freedom of thought, no will, and that everything was suddenly and irrevocably decided. (2)

Thus free competition, or rather, freedom of industry and enterprise, was set loose to run, like a huge untrained monster, its wayward course. (3)

Draft amendments to the Criminal Code pertaining to, inter alia, greater freedom of expression and the introduction of penalties against domestic violence had been submitted to the national Parliament.(4)

Here are the definitions of a lexical unit "freedom": The quality or state of being free, Independent (MWLD); The power or right to act, speak, or think as one wants (OWD); The condition or right of being able or allowed to do, say, think, etc. whatever you want to, without being controlled or limited (CED); Freedom is defined as the state of being free, independent, without restrictions (MWLD). Based on the definitions, the key features of the "freedom" are highlighted: being free, have a right. Common for a wide range of interpreters characteristics represent the main feature of the language sign: "commonality" (Fig. 1).

Freedom is understood as independence, lack of restrictions and restraints and human rights. The key semantic signs allow coming to a common denominator and constructing a common vector of interpretation for all participants of the discursive practice which we will define as discourse of consensus after prof. A. Kaplunenko (Kaplunenko, 2007).

Analyzing notion and its content, it is necessary to emphasize that the mental entity possesses certain characteristic features that help to distinguish it from the concept or term. The notion can be defined as a thought, which summarizes objects by the system of characteristic features common only for these selected objects. The objects are united into a category and separated from others. Developing the theory of notion, it is supposed that the notion is universal and unites native speakers who are participants of discourse. Dialectical thinking depends on consciousness ability to overcome differences within discourse of consensus.

2. In the process of communication, and therefore, interaction, the participants of the discourse may take part in a specific conversation 


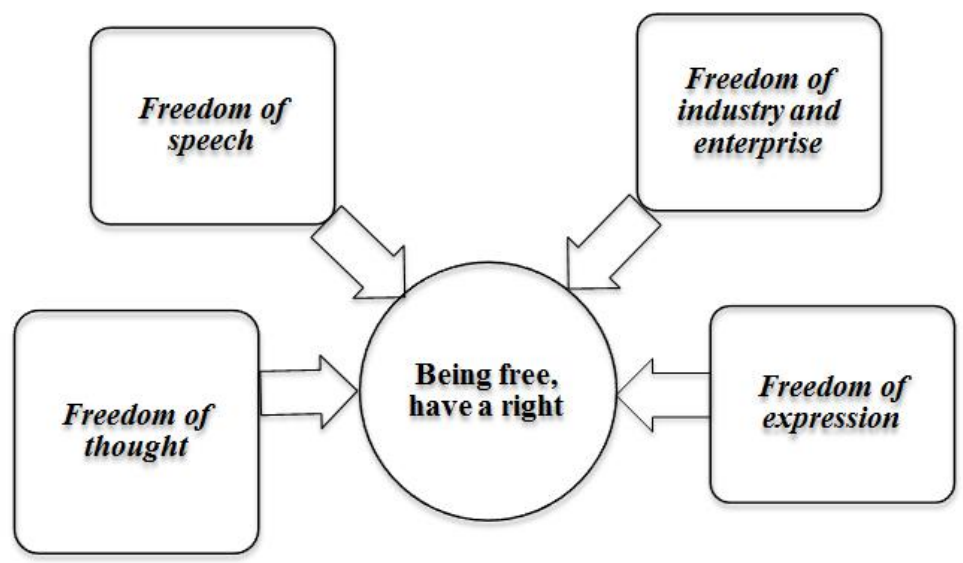

Fig. 1. Vectors of sign interpretation

with expert commentary. So, it is impossible to set apart one more aspect of the classification proposed by prof. A. Kaplunenko (Kaplunenko, 2007). A characteristic feature of discourse of expert community is the use of terms familiar only to a certain range of specialists. The semiotic entities will be interpreted by a layman completely different because of the lack of special knowledge about the object.

"Terminus" is the boundary that originally was a materially planned and therefore meant frontier pillar, border stone, border sign in general. In the Greek language, the word ópos, as well as the word ỏpıruós, from fópfos actually means a furrow, and then a border. "As it is known, the original right to property was a purely religious concept not a legal one. It essentially emerged from the fear of God, fear to hurt the cult that is a total mystery to the strangers as they do not belong to it. If sacred sanctity of anything, that is a part of the cult, had been violated, the disturber would inevitably have suffered terrible punishments from the offended dead" (Florensky, 1990: 218).

Each field, house and other property was separated from neighboring estates by shallow moats and low ramparts with trees that played the role of a certain border. The fence could also serve as a strip of unprocessed land. On certain days of the month and year the landlord went around his property and drove the sacrificial animals before him. The landlord placed unprocessed stones or some wooden blocks called "termes" on the road of animals. The term was a sacred place where sacrifices took place, thus people asked the gods to help them to protect their lands. In ancient times, terms existed among the Hindus, and the sacred rites of setting boundaries were in many respects similar to those of the Ancient Roman.

In other words, the term is primarily the guardian of the cultural boundary: it gives life to the dismemberment and structure, establishes the inviolability of the basic junctures of life. "Being a limit of this area of culture the term belongs to this culture. I will express myself mathematically: any term is a limit value of a culture. Term gives impetus to the emergence of a well-known culture, a cult. So, not without reason the name terminus contains an indication of a certain connection with the cult and a sign of the future tense ("-urus" form)" (Florensky, 1990: 220).

Later, the token terminus is defined as: 1) the area described by its boundaries and limits; 2) definition, ópos, a synodic cannon; here terminus and ópo $\varsigma$ in Latin and Greek accurately convey each other; 3) the appointed time, the fixed day; 4) holiday. 
To sum up the philosopher conducted a very deep analysis, revealing the origins of etymology and the scope of this word. So, term (terminus, ópos) means borders, some boundaries of thought. Metaphorically speaking limited content of the term denotes the boundary of semiotic entities evolution.

Within the expert community, terms are tools of professional thinking; therefore representatives of expert communities demand the term meaning to be clear and unique. In this connection it will be appropriate to assume that terms should be unambiguous, i.e. they should not have a large number of synonyms within a certain expert community. Terms should be accurate, concise and stylistically neutral. The term content and scope are strictly limited one sign corresponds to one meaning within a certain term system. Language signs with a dense content and limited scope that are functioning in discourse of expert community as a result become the language of a special field of scientific knowledge.

Terms should avoid both polysemy and interpretation based on intentional experience or pure feelings. According to Husserl, consciousness as experienced from the firstperson point of view is based on sensory perception. As a result experience is becoming a source of idea creation, which means a person gains knowledge through experience that can be characterized as an individual's cognitive context of interpreting that is unlikely to be appropriate when dealing with the language of experts.

Let's consider a number of examples containing the language sign "freedom".

A Cathay Pacific plane which picks up passengers in Hong Kong and delivers them to Tokyo is exercising its third freedom right. (5)

In order for Cathay Pacific to operate this flight, Canada and the US must grant Hong Kong fifth freedom for the route. Fifth freedom rights are rarely granted since the foreign airline is now competing with domestic airlines for the same traffic. (6)

These fragments of expert discourse contain such terms as "third freedom" and "fifth freedom". When translated into Russian loan translation is applied. However, without additional background knowledge correct interpretation of these terms is not possible, since the numerals (third, fifth) do not bind to "freedom" in aviation context.

Associatively interpreter can correlate the term "third/fifth freedom" with the freedoms of the person enshrined in the Constitution, but this characteristic feature will not lead to the correct vector of interpretation. In discourse of experts these terms should be understood as "freedom of airspace". They constitute nine sets of civil aviation rules that entitle airlines to enter the airspace of another country and land there. The rules were stated as a result of disagreement over liberalization of the International Civil Aviation Convention. Thus, the term "third freedom" refers to the right to carry passengers or cargo from one's own country to another and allows basic international service between two countries.

As for "fifth freedom", it allows an airline to carry revenue traffic between foreign countries as a part of services connecting the airline's own country. It is the right to carry passengers from one's own country to a second country, and from that country to a third country (and so on). Fifth freedom traffic rights are intended to enhance the economic viability of an airline's long haul routes (Fig. 2).

Let us analyze the same language sign but in another expert community.

6DoF refers to the movement of a rigid body in three-dimensional space. Specifically, the body is free to change position as forward/ backward (surge), up/down (heave), left/right (sway) translation in three perpendicular axes, 


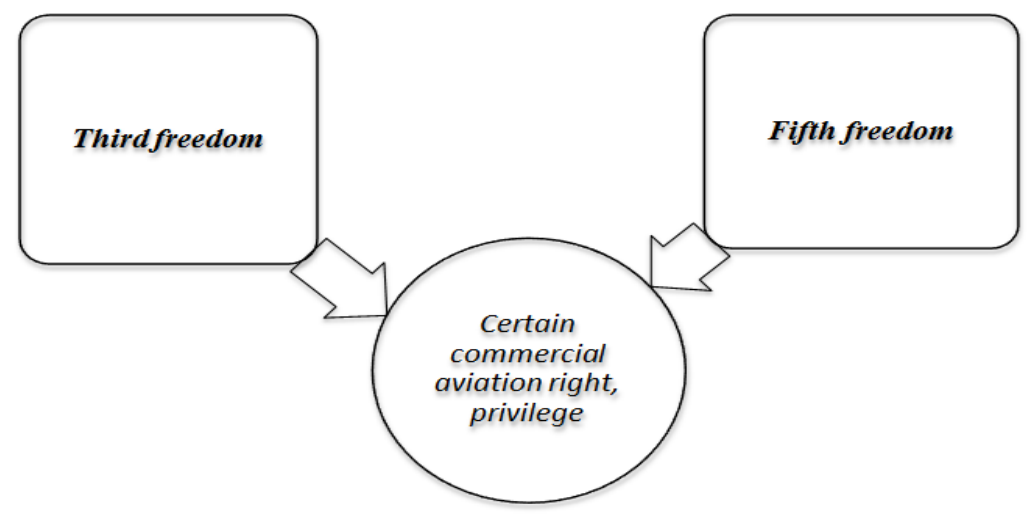

Fig. 2. Term interpretation

combined with changes in orientation through rotation about three perpendicular axes, often termed pitch, yaw, and roll. (7)

Шесть степеней свободы указывает на возможность геометрической фигуры совершать геометрические движения в (трёхмерном) пространстве, а именно: Шесть степеней свободы указывает на возможность геометрической фигуры совершать геометрические движения в (трёхмерном) пространстве, а именно: двигаться вперёд/назад, вверх/вниз, влево/ вправо (в декартовой трёхмерной системе координат), включая повороты вокруг каждой из трёх взаимно перпендикулярных осей (рыскание, тангаж, крен). (7.1)

First of all a translator has to decipher this abbreviation. Scientific texts are full of abbreviations. This is the main characteristic feature of such texts. It tends to compression. On the one hand, they help to compress cognitive information (Alekseeva, 2004: 251) but on the other abbreviations lead to pitfalls.

When translating the abbreviation "6DoF" the translator is guided by the following logic: 6DoF - Six Degrees of Freedom - шесть степеней свободы. Unlike the example (6) community of experts introduces the term "Six Degrees of Freedom" without taking into account enumeration of freedoms from one to six. The numeral "six" in relation to the "degree of freedom" arises because of the ability of a geometric figure to make movements in threedimensional space. Since the movement along each of the three axes does not depend on the movement of the other two and rotation around any of the axes, the movement has six degrees of freedom.

In this example we observe the use of the term, the content of which is known to the participants of expert community discourse, therefore experts' interpretants ${ }^{1}$ aspire to the common object of true reality and are not directional.

In the scientific literature it is generally recognized that terms are words or phrases of a special use that differ from the units of the vernacular language. O. Zjablova in her study of economic texts suggests that terms may go beyond their natural habitat, which is commonly referred to as "languages for special purposes" (Zjablova, 2005). Terminological units often lose their specific features becoming a unit of the vernacular language or converging with everyday vocabulary. However, there is a possibility of a reverse transformation when a unit of vernacular character acquires new characteristics and further becomes a term. The quantity of specific features distinguishing term from everyday lexis depends on 
knowledge branch, type of text, communicative situation, participants of conversation, etc. (Zjablova, 2005: 34-43).

3. I.S. Alexeeva believes that this lexical layer is transmitted through variant correspondences. The neutral vocabulary of a general scientific description in each language has a large number of options that can be used according to context. (Alexeeva, 2004: 268). For example, "importance" - важное значение, актуальность, важная роль; "author" - автор, творец, инициатор, исполнитель; “quote" цитировать, ссылаться, брать в кавычки; “work" - работа, труд, борьба, воздействие "time" - время, наработка, дата, интервал "space" - пространство, протяженность, площадь, пределы.

According to Pamela Faber Benítez "to translate this type of specialized language text, translators must go beyond correspondences at the level of individual terms, and be able to establish interlinguistic references to entire knowledge structures" (Benítez, 2018).

This problem is perfectly described by Huang and Chen "there are cases when one term has many meanings or many terms actually refer to one concept ${ }^{2}$, terminologists always try their best to avoid or even erase such phenomena instead of letting them grow uncontrollable as in the case of ordinary words" (Huang \& Chen, 2001: 158).

It means that a translator of technical texts should also be closet terminologists and be capable of carrying out terminological management as a means of knowledge acquisition. J.Sager analyzing a theory of terminology and a translation process makes a conclusion that terminological theory proceeds from abstract cognitive units called concepts to the identification of appropriate linguistic expressions or terms. His figure illustrates dual approach to of terminology.

\section{THEORY: KNOWLEDGE FIELD $\rightarrow$ CONCEPT $\rightarrow$ TERM $\rightarrow$ USAGE \\ APPLICATIONS : TEXT CORPUS $\rightarrow$ TERM $\rightarrow$ CONCEPT \\ $\downarrow$ \\ KNOWLEDGE FIELD}

It could therefore be concluded that translators only need a minimal theory of terminology in order to find terms which correspond to the same concept in two languages. The reality, however, is more complex: translators often find that they need to establish identity among concepts, to deal with instances where concepts are similar rather than identical, and create target language terms for new concepts (Sager, 2001: 258) Generally speaking, terms should help people describe one concept with the help of one word or word combination. At first sight terms look like special lexical units which allow people understand each other. Unfortunately only start translating one understands that terms make communication very difficult. These lexical units mostly help to build up discourse of expert community. A translator doesn't usually belong to this community that's why some linguists believe that a translator should have a degree in the topic he/she is going to translate.

However, in practice the situation is even more complicated because the information in scientific and technical texts is encoded in terms or specialized knowledge units, which can be regarded as access points to more complex knowledge structures (Benítez, 2018). 
There are several rules how to translate terms: generalization, concretization, transliteration, transcription, explication, changing the order of attributive group, descriptive translation and a loan translation. All these approaches can be attributed not only to the term translation but for any lexical unit. It means that there is no onesize-fits-all formula to follow. Dealing with pure scientific texts a translator's aim is to achieve the symmetry between the original and translation. Hervey and Higgins (Hervey, Higgins, 2002: 25) postulate the philosophy of minimizing difference as a central goal of translation. But we must remember that "languages differ essentially in what they must convey and not in what they can convey" (Jakobson, 1960/1987: 264). Symmetry in many cases kills the original, because when a source text and a target one are symmetric, there can't be plurality of translation. But at the same time it is known that scientific texts and especially translation of terms should avoid duality and polysemy.

For example, it's seldom possible to say "to clean after the welding" (убрать мусор после сварки), only "to do post-welding cleaning will be an adequate translation" (Komissarov, 1990: 115). The first variant is quite understandable but it isn't an expert community term. Moreover, the second variant of translation is asymmetric.

First, the differences in grammatical and semantic structures of different languages prevent a translator from achieving symmetry. M.Bakker, C. Koster and K. van Leuven-Zwat explain it through shifts. "Shifts of translation can be distinguished from the systemic differences which exist between source and target languages and cultures. Systemic differences, which pertain to the level of competence, are part of the opening conditions for translation. Shifts, on the other hand, result from attempt to deal with systemic differences. Translation involves the transfer of certain values of expression or content across a semiotic border; shifts are concomitant with this transfer. The relation between any two systems confronted in the process of translation is asymmetric, and the way the transfer is carried out is not determined a priori" (Bakker, Koster, van Leuven-Zwat, 1993: 226).

In every particular situation a translator has to choose between the term and notion. It means that shifts are possible even during the process of term translation. These shifts help to express the deepest implicatures of a text. And these shifts are not structural but cognitive ones.

Second, when the boarders are broken and a text becomes a popular-scientific one it's very difficult to find symmetry, a balance between terms in a source and target texts. Why does it happen? In most cases the first reason is transformation of the term in a popular-scientific text. There are a lot of them on the Internet nowadays. The term becomes notion because the text is aimed not only for specialists but different people interested in this sphere of knowledge. An expert community term should be transformed into the notion otherwise a translator won't be able to achieve communicative effect.

Moreover, the difference between a scientific text and scientific-popular is very slight and invisible. Sometimes scientists who work in different fields can understand a translated text only if terms are translated as notions. Notions bring scientists together opening doors to crossdisciplinary researchers. Transferring a term into notion a translator usually has to simplify, avoid repetitions, and use explications which are known as "universals of translation" (Baker, 1993: 243). Very often it presupposes that translation meets interpretation. To interpret translator must be an expert in the field because "if you can't explain it simply, you don't understand it well enough" Albert Einstein.

They reached the old Ford as the blue hour ended. (8) 
Они добежали до старого «форда»как раз тогда, когда кончился час синевы.(8.1)

The term blue hour is translated by term that's why only experts belonging to expert community discourse can understand and interpret it.

Blue hour is a photographic term for twilight, during which the brightness of the sky is still sufficient to obtain a normal exposure in the corresponding sections of the frame. (9.1)

Режимное время - фотографический термин, обозначающий сумерки, во время которых яркость небосвода ещё достаточна для получения нормальной экспозиции на соответствуюших участках кадра.(9)

This example illustrates the transformation of the term into notion in the process of translation. This is an abstract from instruction. Usually such texts are aimed at common people, not professionals. A translator tried to make it comprehensive and easy.

During the second experiment, by using higher rates of data transmission, camera operation that excluded sudden movements and panning and new screen technologies, it was possible to see the images without having to work in a dark or semi-dark room. (10)

B ходе второго эксперимента 6 результате использования высокоскоростной передачи данных, работь с камерой, исключавшей неожиданные движения $u$ панорамирование, а также новых технологий проектирования изображения на экран удалось получить изображение без необходимости работать в темном или затемненном помещении.(10.1)

Again the term is translated for experts, for those who perceive and understand terms of this expert community.

Its two or three-way pan head enables smooth, panoramic panning at an array of angles. (11)
Штативная 3D головка обеспечивает возможность плавной панорамной съемки под разными углами. (11.1)

Second example shows and proves the idea of terms duality. Translating a term by a notion a translator very often has to interpret. Precisely during interpretation which is a part of translation one can see "fusion of horizons". There are three aspects: a sender of the message and - a translator - a receiver of the message. In "Afterword" to Truth and Method Gadamer writes: "what I described as a fusion of horizons was the form in which this unity [of the meaning of a work and its effect] actualizes itself, which does not allow the interpreter to speak of an original meaning of the work without acknowledging that, in understanding it, the interpreter's own meaning enters in as well" (Gadamer, 1992: 576). This method of terms translation is very complicated. A translator can't use transcription or transliteration. Translation of terms by notions needs the deepest text and context analysis that differs very much from translation terms by terms (Table 1). Translation of terms by terms should avoid interpretation at all.

Having examined the semiotic essence within the classification of discursive practices, which is mainly based on socialization of viewpoints of discourse participants, it can be concluded that:

1) within discourse of consensus participants use notions with limited scope and content constructing the interpretation vector on the basis of key characteristic features of the notion;

2) discourse of expert community forms the basic nomenclature, a system of names used in a particular specialist field. The system of naming things within discourse of expert community helps to differentiate terms from notions. Terms have the most narrow scope and specific content, which causes ambiguity of the term and manifests final interpretation of a language sign; 
Table 1

\begin{tabular}{|c|c|c|}
\hline Term & Term translation & Notion translation \\
\hline Bokeh & Бокэ & Размытие \\
\hline Aberration & Аберрация & Отклонение \\
\hline Blue hour & Режимное время & Сумерки \\
\hline Interpolation & Интерполяция & Восстановление \\
\hline Panning & Панорамирование & Панорамная съемка \\
\hline Bayonet & Байонет & Крепление \\
\hline
\end{tabular}

3) translating scientific texts a translator must avoid ambiguity although polysemy and synonymy frequently occur in such texts. It is obvious that a translator's aim is to find a path from concepts to terms and vice versa. The problem is to transfer from the discourse of expert community to the discourse of the consensus simultaneously translating sense. It appears that to bring communicants together a translator very often has to change terms into notions.

1 The term interpretant is used after Charles Sanders Peirce's triadic theory of the sign.

2 Concept is an abstract or generic idea generalized from particular instances (MWLD).

\section{References}

Alekseeva, I.S. (2004). Introduction into Translatology. Moscow: Akademiya.

Anderson, S. (2005). Collins English Dictionary. 9th ed. NY: HarperCollins. 1888 p.

Baker, M (1993). Corpus linguistics and Translation Studies. Implications and Applications. Text and Technology: In Honour of John Sinclair. Amsterdam: John Benjamins.

Bakker, M., Koster, C. and van Leuven-Zwart, K. (2001). Shifts of translation. Routledge Encyclopedia of translation studies. London and New York: Routledge.

Benitez, P.F. The cognitive shift in terminology and specialized translation. Available at: http:// rua.ua.es/dspace/bitstream/10045/13039/1/MonTI_01_10.pdf

Fairclough, N. (1992). Critical Language awareness. London: Longman. P. 22.

Fasold, R. (1990). Sociolinguistics of Language. Oxford: Blackwell. 360 p.

Florensky, P.A. (1990). Writings. Vol. 2. Moscow: Pravda. 448 p.

Gadamer, Hans-Georg. (1992). Truth and Method. 2nd ed. Trans. Joel Weinsheimer and Donald G. Marshall. N.Y.: Crossroad.

Hegel, G.W.F. (1998). The science of logic. Moscow: Mysl. 172 p.

Hervey, S. and Higgins, I. (2002). Thinking French Translation: A Course in Translation Method. French to English. London: Routledge (1st publ. 1992).

Huang, J and Chen, C. (2001). Introduction to Bilingual Lexicography (Revised Editon). Beijing: The Commercial Press.

Ivlev, Ju.V. (2001). Logic. Moscow: Logos. 272 p.

Jakobson, R.O. (1960/1987). Linguistics and Poetics. K. Pomorska and S. Rudy (eds), Language in Literature, Cambridge, MA: Belknap Press of Harvard University Press.

Kaplunenko, A.M. (2007). Concept - Notion - Term: evolution of semiotic entities in the context of discursive practices. Irkutsk: ISLU.P. 115-120. 
Komissarov, V.N. (1990). Translation theory. Moscow: Vysshaya shkola.

Krapivkina, O.A. (2016). Concept vs notion: fenomenologism vs conventionalism. Tolyatti: TSU.P. 95-98.

Kwong, K. (1988). Towards Open Skies and Uncongested Airports: An Opportunity for Hong Kong. Hong Kong: The Chinese University Press, 1988. 86 p.

Laviosa-Braithwaite, S. (2001). Universals of translation. Routledge Encyclopedia of translation studies, London and New York: Routledge.

Merriam-Webster's learning dictionary. American English Dictionary for Students of ESL, EFL, and the TOEFL Test. Available at: www.learnersdictionary.com.

Sager, J.C. (2001). Terminology, theory. Routledge Encyclopedia of translation studies. London and New York: Routledge.

Saintcrow, L. (2006). Working for the Devil. NY: Warner books. 416 p.

Sigwart, H. (2008). Logic Vol. 1. The Judgment, Concept, and Inference. Moscow: Territor of Future. $80 \mathrm{p}$.

Turnbull, J. (2000). Oxford Wordpower Dictionary. Oxford: Oxford University Press. 795 p.

Tyurneva, T.V. (2012). Analysis of linguistic and semiotic context of EDUCATION: concept, notion, term: on the material of the English language. Philology Cand. Diss. Irkutsk. 202 p.

Zjablova, O.A. (2005). Stratification of economic texts and their specific terms // Voprosy filologii. Moscow: Severnyj Gorod. 102 p.

\section{Дихотомия термин-понятие:}

\section{переводческий аспект}

Т.В.Тюрнева, Н.В.Щурик

Иркутский государственный университет

Россия, 664003, Иркутск, ул. Карла Маркса, 3

В данной статье авторы ставят перед собой задачу провести лингвосемиотический анализ понятия и термина, предложить дифференциацию ментальных сущностей по признаку принадлежности к определенному типу дискурсивного сообщества, а также проиллюстрировать особенности интерпретации понятия и термина и сферу их употребления. В статье приводится исследование семиотических сушностей в соотношении с определенными дискурсивными практиками, что позволяет дифференцировать термин и понятие. Наиболее ярко проблема дихотомии термин-понятие проявляется в процессе перевода. Очень часто переводчику приходится переводить термин понятием, что требует особых умений и навыков. При трансформации термина в понятие переводчик вынужден адаптировать и переводить не только лексические единицы, но и дискурсы.

Ключевые слова: понятие, термин, дискурс согласований, дискурс экспертного сообщества, знак, интерпретация, перевод, симметрия, асимметрия.

Научная специальность: 10.02.00 - лингвистика. 